\begin{tabular}{|c|c|c|}
\hline$A$ & $\begin{array}{c}\text { International Journal of Current Research } \\
\text { and Academic Review }\end{array}$ & \\
\hline $\begin{array}{l}\text { EXCELLENT } \\
\text { PUBLISHERS } \\
\end{array}$ & $\begin{array}{c}\text { ISSN: 2347-3215 (Online) } \\
\text { Journal homepage: holume } 5 \text { htp://www.ijcrar.com } \\
\end{array}$ & \\
\hline
\end{tabular}

doi: $\underline{\text { https://doi.org/10.20546/ijcrar.2017.504.012 }}$

\title{
Conservation of Biodiversity and Sustainable Use of Medicinal Plant
}

\author{
Teena Agrawal* and Priyanka Danai
}

Department of Bioscience and Biotechnology, Banasthali Vidyapith, India

*Corresponding author

\section{Abstract}

Biodiversity or biological diversity includes all living organisms such as plants, animals and microbes etc. and the genetic differences among them. It exists at species, community ecosystem and landscape scales. It is important for four basic reasons such as morality, aesthetics economics and the service that is provided to society. Biodiversity is considered at three main levels including species biodiversity, genetic biodiversity, functional biodiversity and ecosystem biodiversity. Relative to the variety of habitats, biotic communities and Ecological processes in the biosphere, biodiversity is important in no. of ways such as promoting the aesthetic value of the natural environment, contribution to our natural environment, and maintaining the integrity of the environment. Plants have been used for medicinal purposes long before. Medicinal use of plant seems to be developed through observation of wild animals and by trial and error. Medicinal plants play an important role not only as traditional medicines but also as trade commodities meeting the demand of distinct markets. India has $2.4 \%$ of world's area and with $8 \%$ of global biodiversity and about one fifth of all the plant found in India are used for medicinal purposes. Methods of folk healing throughout the world commonly use herbs as part of their traditions. DNA banking is considered as means of complimentary method for the conservation of the plant species by preserving their genomic DNA at low temperature. The substantial contribution to human health and well being by medicinal plant species is now widely understood. Therefore plant Biotechnology offers new means of improving biodiversity conservation rather than threatening biodiversity in various ways.
\end{abstract}

\section{Article Info}

Accepted: 10 April 2017

Available Online: 20 April 2017

\section{Keywords}

Biodiversity, Ecosystem, Medicinal plant, Traditional medicine, DNA banking, Plant Biotechnology.

\section{Introduction}

The term biodiversity encompasses a broad spectrum of biotic scales, from genetic variation within species to biome distribution on the planet (Wilson, 1992; Gaston, 1996, Purvis and Hector, 2000; Mooney, 2002). Biodiversity conservation was first defined as a science less than three decades ago (Meine, 2010), but is now well developed, multidisciplinary research endeavor (Sodhi and Ehrlich, 2010). India occupies only $2.4 \%$ of the world's land area but its contribution to the worlds biodiversity is approximately $8 \%$ of the total no. of species (Khoshoo, 1996), which is estimated to the 1.75million. Myer's and Colleagues (2000) 'hotspots' concept has already become part of the classic conservation lexicon, defining areas with high species endemism and severe degradation by humans. A recent study has compiled indicators on the state of biodiversity and reported overall decline with no significant recent reduction in the decline rate. This strongly suggests that 
the rate of biodiversity loss is not slowing down (Butcharet et al., 2010).

Medicinal plants are very important for the rural communities all over the world. Medicinal plants are the essential components of primary health care especially for rural communities in developing countries. Plants have been an indispensible source of both preventive and curative medicinal preparations for human beings (Dery et al., 1999). Medicinal plants also play an important role in industrial production of pharmaceutical as they are the source of therapeutic agents (Lambert et al., 1997).

It is known that about 13,000 species of medicinal and aromatic plants are used in traditional medicines and cosmetics all over the world (Wilkinson et al., 2002). The market for Ayurvedic medicines is estimated to be expanding at 20\% annually in India (Subrat, 2002). Across the country the forests are estimated to harbor $90 \%$ of India's total medicinal plants diversity. Only about $10 \%$ of the known medicinal plants of India are restricted to non- forests habitats (Wakdikar, 2004). Out of 18,665 plants the classic system of medicines like Ayurved, Siddha and Unani make use of only about 3000 plants for various purposes (Schippmann et al., 2006).

The demand for medicinal plants is increasing very rapidly not only in developing countries but also in developed countries as drug, food supplement and cosmetics (Ramawat et al., 2004). India is one of the worlds 12 hotspots having the largest plant biodiversity it has almost 45,000 plant species, out of which 15,000 20,000 are used for medicinal value (Ramawat and Goyal, 2008).

Biotechnological applications play an important role in the multiplication and genetic enhancement of the medicinal plants by using in-vitro regeneration and genetic transformation technique. Some medicinal plants such as Commiphora wightii, Curculigo orchiodes and Chlorophytum borivilanum are endangered due to exploitation and urbanization and this promoted biotechnologists to develop alternative technology for the production of their bioactive molecule and micro propagation of these plants.

\section{Biodiversity and its Importance}

The interest in the quantification and valuation of biological diversity is largely motivated by findings from natural scientists that biodiversity is imperiled by human activities (Wilson, 1992), especially the destruction of natural habitats (Primack, 2000). Biodiversity has a key role in maintaining healthy ecosystems and thereby sustaining ecosystem services to the ever-growing human population.

It is currently generally accepted that biodiversity plays an important role in the extent and stability of the services provided by ecosystem (Naeem et al., 2009). Degradation of natural forests is a global problem (Guppy, 1984; Sayer and Whitmore, 1991). People have been destroying forests for millennia ever since agriculture was started (William, 1989).

The manifestation of biodiversity is the biological resources and ecological processes of which they are part. Biodiversity is therefore considered at 3 major levels.

Species diversity - species biodiversity is the variety of species within a habitat or a region. Ecologists have found species diversity difficult to define and measure and this may in fact reflect the possibility that it is a 'non concept' (Hurlbert, 1971). Though the global biodiversity crisis is typically measured at the species level, the effects of species loss occur first at the population level (Ceballos and Ehrlich, 2002).

Genetic diversity - genetic diversity has principally been the domain of evolutionary biologists (Wright, 1920; Fisher, 1930). Genetic diversity is the clay of evolution, the base material on which adaptation and speciation depend. There is a delicate interdependence between biological and genetic diversity. For instance, in agronomy there have long been efforts to increase crop yield by planting genetically diverse varieties within a single field (Wolfe, 1985; Smithson and Lenne, 1996).

Ecological diversity- ecological diversity relates to the different forms of life which are present in a particular site. Global change has four interacting components climate, atmospheric composition, land use and ecological diversity (Walker et al., 1999). In particular it has been hypothesized that ecological diversity may contribute importantly to various aspects of ecosystem stability (Walker, 1995; Hobbs et al., 1995; Peterson and Holling, 1998). In an ecological framework the diversity concept relies on the apportionment of abundances into a no. of animal or plant categories forming the ecological community.

Ecosystem provides many goods and services that are crucial to human survival. These goods and services 
include food, fiber, fuel and energy. Ecosystem also plays an important role in biogeo chemical processes that underline the functioning of the earth ecosystem. Biodiversity provides an important safety- net during times of food insecurity, particularly during times of low agricultural production (Anglesen and Wunder, 2003; Karjalainen et al., 2010), during other seasonal or cyclic food gaps (Arnold, 2008; Vinceti et al., 2008) or during periods of climate induced vulnerability (Cottu and Tirado, 2008).

In many rural locations, particularly areas that lack basic infrastructure and market access, the collection of wild resources provides considerable subsistence support to local livelihoods (Delang, 2006).

\section{Traditional Medicines and their use}

Plants have been used for the medicinal purposes from long time ago. Many drugs listed as conventional medications were originally derived from plants. Ayurveda, Siddha, Unani and Folk (tribal) medicines are the major systems of indigenous medicines. Among these, Ayurveda is the most developed and widely practiced in India.

Gathering of high value products such as Mushroom, Medicinal plants also continue in developed countries for cultural and economic reasons (Jones et al., 2002). Desert areas harbor a high diversity of medicinal plants. In countries where the dominant health care system is based on allopathic medicine or where traditional medicine has not been incorporated into the national health care system, traditional medicine is often termed as "Complementary" or "non- conventional medicine" (WHO).

The pharmacopoeia of folk seties as well as professional medicinal systems like Chinese, Ayurvedic, Unani and biomedicine contain thousands of medicines made from leaves, roots, herbs, bark, mineral substances and other materials found in nature (Good, 1980; Gesler, 1992). In Amazon at least 1,300 plant species are being used as medicines, poisons or narcotics (Schultes, 1979). For large no. of rural and urban poor people in the Amazonia region medicinal plant offers the treatments for both minor and serious problems (Elisabetsky and Wannamacher, 1993).

In recent years, traditional healing in distant forest areas has come under pressure from novel diseases such as Influenza and Tuberculosis (Shapiro, 1993) that have often revealed the superiority of 'White man's capsule'. The links between traditional medicine and biodiversity are imperative (Anyinam, 1995) particularly when considering the importance of former as a source of primary health care to 80 percent of the world's population (Alves and Rosa, 2005).

\section{Sustainable Use of Medicinal Plant}

Medicinal plants are the basic necessities for the livelihood of poor communities all over the world. Out of c. 32000 species of higher plants (Prance, 2001) more than $10 \%$ are used medicinally. According to the recent study it has been estimated that Pakistan especially northern Pakistan and Baluchistan not only harbours no. of endemic species but also is the centre of origin and radiation centre of many genera such as Astragalus, Cousinia and Allium. Shinwari et al., (2009) reported the presence of inhibitory substance in medicinal plant and thus provided the information regarding some of the traditional use of the medicinal plants.

In Bhutan medicinal plants have become an indispensable tool for treatment and poverty alleviation (Wangchuk, 2007). The sustainable use of MAPs in Bhutan are guided by sound legal frameworks and acts such as forest Act 1969, Plant Quarantine Act of Bhutan 1993, forest and Nature conservation act of Bhutan 1995 etc. (Yaganagi, 2006; Tshering, 2006). The demand for herbal medicine is not large enough but growing (Srivastava, 2000). For medicinal plants with limited abundance and show growth, destructive harvesting generally results in resource exhaustion and even species extinction (Larsen and Olsen, 2007; Baker et al., 2007). Therefore the sustainable use of medicinal plants should be considered and good harvesting practices must be formulated.

\section{Biotechnological approaches for the conservation of medicinal plant}

Direct manipulation of DNA sequences to alter gene expression in medicinal plants is an area that is ripe for expansion. By bringing herbs into cultivation traditional and biotechnological plant- breeding techniques can be applied at the genetic level to improve yield and to modify their potency or toxicity. In Mentha spp., biosynthetic pathways have been engineered to modify essential oil production in the trichome to enhance the resistance of the plant to fungal infection and abiotic stresses (Veronese et al., 2001). 
The utilization of plant cells for the production of natural or recombinant compounds has gained increasing attention over past decades (Canter et al., 2005). The secondary metabolites are known to play a key role in the adaptation of plants to their environment but also represent an important source of Pharmaceuticals (Ramachandran Rao and Ravishankar, 2002). In some countries more than two- thirds of the existing habitat types are considered endangered due to industrialization, urbanization, overexploitation and Urbanization and changes in land use. The application of biotechnological techniques to medicinal plants has received considerable interest, especially when the final product is defined, purified and natural.

Table.1 Important Medicinal plant and their use

\begin{tabular}{|c|c|c|c|c|}
\hline Common name & $\begin{array}{l}\text { Botanical } \\
\text { name }\end{array}$ & Part used & Medicinal uses & Plant \\
\hline Ashwagandha & $\begin{array}{l}\text { Wthania } \\
\text { somnifera }\end{array}$ & Root, Leaf & $\begin{array}{l}\text { Restorative tonic, } \\
\text { Stress, nerve } \\
\text { disorder }\end{array}$ & \\
\hline Bael & $\begin{array}{l}\text { Aegle } \\
\text { marmelous }\end{array}$ & $\begin{array}{l}\text { Fruit, } \\
\text { Bark }\end{array}$ & $\begin{array}{l}\text { Diarrhoea, } \\
\text { Dysentery, } \\
\text { Constipation }\end{array}$ & \\
\hline Bhumi Amla & $\begin{array}{l}\text { Phyllanthus } \\
\text { emblica }\end{array}$ & $\begin{array}{l}\text { Whole } \\
\text { plant }\end{array}$ & $\begin{array}{l}\text { Jaundice, } \\
\text { Constipation, } \\
\text { Reduce fever, } \\
\text { Aenimic }\end{array}$ & \\
\hline Gritkumari & Aloe vera & leaves & $\begin{array}{l}\text { Wound healing, } \\
\text { skin burns and } \\
\text { ulcer }\end{array}$ & \\
\hline Mehndi & $\begin{array}{l}\text { Lawsennia } \\
\text { iermis }\end{array}$ & Leaf, seed & $\begin{array}{l}\text { Burning, steam, } \\
\text { anti inflammatory }\end{array}$ & \\
\hline Neem & $\begin{array}{l}\text { Azardirchata } \\
\text { indica }\end{array}$ & Rhizome & $\begin{array}{l}\text { Analgesic, } \\
\text { sedidative } \\
\text { hypertension, }\end{array}$ & \\
\hline Peppermint & Mentha pipertia & $\begin{array}{l}\text { Leaves, } \\
\text { oil }\end{array}$ & $\begin{array}{l}\text { Digestive, pain } \\
\text { killer }\end{array}$ & \\
\hline Tulsi & $\begin{array}{l}\text { Ocimum } \\
\text { sanclum }\end{array}$ & $\begin{array}{l}\text { Leaves, } \\
\text { seed }\end{array}$ & $\begin{array}{l}\text { Cough, cold, } \\
\text { bronchities }\end{array}$ & \\
\hline
\end{tabular}

The manipulation of medicinal plant is well known and accepted both by scientist and consumes if the pathways and product yield can be optimized to create precursors for semi synthesis (e.g. Beccatin III to Paclitaral), food component (e.g. Vitamins) pesticide residence (Atropa belladonna) (Saito, 1994; Saito, 1992) and cellular 
storage condition as shown for Mentha $\times$ Pipertia with enhanced resistance against fungal attack and abiotic stress (Veronese et al., 2001).

In present day the science of biotechnology has availed us with the tools and techniques for mass cloning and improvement in medicinal plants. Cultivation of medicinal plants especially high value medicinal plants is creating new dimension in the field of agriculture. To improve and conserve medicinal biodiversity, India has been reported (Alternative medicinal News 2008) to be making efforts for cultivation, collection, characterization and conservation of medicinal plants by restoring their genetic resource for commercial cultivation.

\section{Conservation of Biodiversity}

Biodiversity at all its levels, genetic species and as intact ecosystems can be best preserved by both In-situ and exsitu conservation method.

In In situ conservation of crop genetic resources sometimes not been given importance. In Himalayan region a no. of protected areas - biosphere reserves, national parks and wildlife sanctuaries are in existence and are proposed. Rawat (1994) has proposed potential areas for plant conservation in various Biogeography zones of Himalayas.

For ex-situ conservation in Himalayas region, Khoshoo (1993) emphasized the need of seed, organ, tissue or gene banks, although these can be established at minimal cost because of the proximity of glaciers in the region.

The traditional farming systems have a key role in in-situ conservation of plant diversity. The traditional farming systems were developed by farmers over years of experience to suit specific ecological conditions with a view attaining stability and diversification in production (Singh and Misri, 1995). Gadgil and Berkes (1991) refer that various traditional ecosystem approaches require a belief system which includes a no. of prescription for restrained.

People's participation is very important to integrate ecosystem conservation and rural development as it is necessary to know the needs for they depend on a particular ecosystem (Khoshoo, 1993). Thus folklore surveys are necessary in remote tribal areas to assess the potential of traditional conservation values such as sacred plants, traditional restraints, religious beliefs about certain plants etc. and this background information with obviously help in biodiversity conservation programs.

The working linkages between the centers such as Wildlife Ministry of Environment \& Forests, Botanical India, Zoological Survey of India, National Bureau of Plant Genetic Resources, Wildlife Institute of India, Forest Research Institute, G.B. Pant Institute of Himalayan Environment and Development etc. are being established under the programmes and the well established institutions engaged in the participating country are important for exchanging the information they have. Therefore, such linkages may be used for collecting information of biodiversity including the extinct and endangered plants as well as sites for their conservation.

\section{Acknowledgement}

Authors are thankful to Banasthali Vidyapith for giving us place to study

\section{References}

Alternative Medicine News. 2008. India to Step up Allocation for Cultivation of Medicinal Plants.

Alves, R.R.N., Rosa, I.L. 2005. Why study the use of animal products in traditional medicines? J. Ethno Biol. Ethno Med., 1: 1-5. 10.1186/1746-4269-1-1.

Anyinam, C. 1995. Ecology and Ethno medicine: Exploring Links between Current Environmental Crisis and Indigenous Medical Practices. Social Sci. Med., 40(3): 321-329. 10.1016/0277-9536(94) E0098-D.

Baker, D.D., Chu, M., Oza, U., Rajgarhia, V. 2007. The value of natural products to future pharmaceutical discovery. Nat. Prod. Rep., 24: 1225-1244. doi: 10.1039/b602241n.

Butchart, S.H.M., et al. 2010. Global biodiversity: Indicators of recent declines. Sci., 328: 1164-1168.

Canter, P.H., H. Thomas and E. Ernst. 2005. Medicinal plants into cultivation: opportunities and challenges for biotechnology. Trends Biotechnol., 23: 180-185.

Ceballos, G., Ehrlich, P.R. 2002. Mammal population losses and the extinction crisis. Sci., 296(5569): 904-7 doi: 10.1126/ Science Pmid: 1069349.

Cotter, J., and R. Tirado. 2008. Food security and climate change: the answer is biodiversity. A review of scientific publications on climate change adaptation in agriculture, Exeter: Greenpeace. 
Delang, C.O. 2006. 'The Role of Wild Food Plants in Poverty Alleviation and Biodiversity Conservation in Tropical Countries', Progress in Develop. Studies, 6(4): 275-286.

Elisabetsky, E., Wannamacher, L.1993. The status of ethno pharmacology in Brazil. J. Ethno Pharmacol., 38: 137-143.

Elliot, S. \& Brimacombe, J. 1986 The Medical Plants of Gunung Leuser National Park, Indonesia, WWF, Gland, Switzerland.

Fisher, R.A. 1930. The Genetical Theory of Natural Selection, Oxford University Press, Oxford

Gadgil, M. and F. Berkes. 1991. Traditional resource management systems. Res. Manage. Optimization, 8: $127-141$.

Gaston, K.J. 1996. what is biodiversity? In K.J. Gaston (ed.), Biodiversity: a biology of numbers and difference. Blackwell Science, Oxford, pp. 1-9.

Gesler, W.M. 1992. Therapeutic landscapes: medical Issues in Light of the new cultural geography. Social Sci. Med., 34(7): 735-746. doi: 10.1016/0277-9536(92)90360-3.

Good, C. 1980. In: Conceptual and Methodological Issues in Medical Geography. Meade MS, editor. University of North Carolina at Chapel Hill, Studies in Geography, Ethno-medical Systems in Africa and the LDCs: Key Issues in Medical Geography; pp. 93-116.

Guppy. 1984. Tropical Deforestation: a Global Review. Foreign Affairs, 62407: 928-965.

Hector, A., et al. 1999. Plant diversity and productivity experiments in European Grasslands, Sci., 286: 1123-1127.

Hobbs, R.J., Groves, R., Hopper, S.D., Lambeck, R.J., Lamont, B.B., Lavorel, S., Main, A.R., Majer, J.D. and Saunders, D.A. 1995. function of biodiversity in Meditterranean ecosystem in Australia. The function of biodiversity in Mediterranean ecosystems (ed. by G.W. Davis and D.M. Richardson), pp. 233-284. Ecol. Studies, 109: Springer Verlag, Heidelberg.

Hurlbert, S.H. 1971. The nonconcept of species diversity: a critique and alternative parameters. Ecol., 52: 577-586.

Jones, E.T., R.J. McLain \& J. Weigand. 2002. Nontimber forest products in the United States, Lawrence, USA, University Press of Kansas.

Khoshoo, T.N. 1993. Himalayan biodiversity conservation - An overview pp. 5 -35. In. U. Dhar(ed). Himalayan Biodiversity- Conservation Strategies. Gyanodaya Prakashan, Nainital.

Larsen, H.O., Olsen, C.S. 2007. Unsustainable collection and unfair trade? Uncovering and assessing assumptions regarding Central Himalayan medicinal plant conservation. Biodiversity Conserv., 16: 16791697.doi: 10.1007/s10531-006-9039-4.

Meine, C. 2010. Conservation biology: past and present, In: Conservation Biology for All, N.S. Sodhi \& P.R. Ehrlich (Eds.), 7-26, Oxford University Press, ISBN 0199554234, Oxford, United Kingdom.

Peterson, G., Allen, C.R. and Holling, C.S. 1998. ecological resilience, biodiversity and scale. Ecosystem, 1: 6-18.

Prance, G.T. 2001. Discovering the Plant world, Taxon., 50: $345-359$.

Primack, R. 2000. Extinction, Causes of. In Simon Levin, ed., Encyclopedia of Biodiversity volume 2. San Diego: Academic Press, 697-713.

RamachandraRao, S. and G.A. Ravishankar. 2002. Plant cell cultures: chemical factories of secondary metabolites. Biotechnol. Adv., 20: 101-153.

Rawat, G.S. 1994. Protected areas and conservation of rare endemic plants in the Himalaya, pp. $89-101$. Iq. Y.S. Pangtey and R.S. Rawal (eds). High Altitudes of Himalaya, Gyanodaya Prakashan, Nainital.

Saito, K. 1992. Transgenic herbicide-resistant Atropa belladonna using an $\mathrm{Ri}$ binary vector and inheritance to the transgenic trait. Plant Cell Rep., 21: 563-568.

Saito, K. 1994. [Molecular genetics and bio-technology in medicinal plants: studies by transgenic plants]. Yakugaku Zasshi, 114(1): 1-20.

Schultes, R.E. 1979. The Amazonia as a source of new economic plants. Economic Bot., 33: 259-266.

Shapiro, R.L. 1993. The effects of tropical deforestation on human health, The PSR Quartely, 3: 126-135.

Shinwari, Z.K., I. Khan, S. Naz and A. Hussain. 2009. Screening of medicinal plants of Pakistan for their antibacterial activity. Afr. J. Biotechnol., 8(24): 7082-7086.

Singh, J.P. and Bimal Misri. 1995. Traditional forage management practices, pp. 312- 322. In: C.R.Hazra and Bimal Misri (eds.), New Vistas in Forage Production, IGFRI, Jhansi.

Sodhi, N.S. \& Ehrlich, P.R. 2010. Conservation Biology for All, Oxford University Press, ISBN0199554234, Oxford, United Kingdom.

Srivastava, R. 2000. Studying the information needs of medicinal plant stakeholders in Europe. Traffic Dispatches, 15: 5. Pp. 75-77.

Tshering, T. 2006. The Role of BAFRA in the Conservation of Medicinal Resources. In Proceedings of Bhutan-Japan Joint symposium on Conservation and Utilization of Himalayan 
Medicinal Resources. Thimphu: ITMS and SCDHMR, Bhutan.

Veronese, P., et al. 2001. Bioengineering mint crop improvement. Plant Cell Tissue Organ Cult., 64: 133-144.

Veronese, P., et al. 2001. Bioengineering mint crop improvement. Plant Cell Tissue Organ Cult., 64: 133-144.

Walker, B. 1995. Conserving biological diversity through ecosystem resilience, Conservation Biol., 9: 747-752.

Walker, B.H., Steffen, W.L., Canadell, J. and Ingram, J.S.I. (Eds.) 1999. Implications of global change for natural and managed ecosystem: a synthesis of GCTE and related research. IGBP book series no. 4, Cambridge university press.

\section{How to cite this article:}

Teena Agrawal and Priyanka Danai. 2017. Conservation of Biodiversity and Sustainable Use of Medicinal Plant. Int.J.Curr.Res.Aca.Rev. 5(4), 82-88. doi: https://doi.org/10.20546/ijcrar.2017.504.012
Wangchuk, P. 2007. Herbal Remedies and Utilization of Medicinal Resources in Bhutan. In Book of Abstracts on International Workshop on Herbal Medicinal Plants and Traditional Herb Remedies. Hanoi: Vietnam. pp 6.

World Health Organization (WHO). 2002. Traditional medicine strategy 2002-2005. http://whqlibdoc.who.int/ hq/2002/WHO EDM TRM 2002.1. Pdf.

Yaganagi, M. 2006. Bhutan's Position on the Access to Biological Resources and the Protection of the Associated Traditional Knowledge: The Biodiversity Act of Bhutan 2003. In Proceedings of Bhutan-Japan Joint Symposium on Conservation and Utilization of Himalayan Medicinal Resources, Thimphu: ITMS and SCDHMR, Bhutan. pp 17-28. 